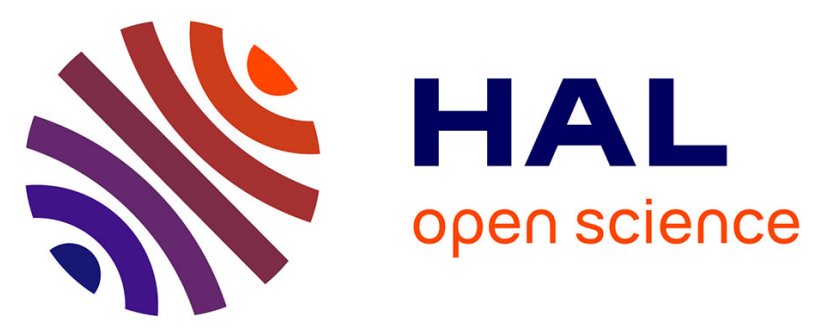

\title{
Investigation of mercury concentrations in fur of phocid seals using stable isotopes as tracers of trophic levels and geographical regions
}

\author{
Aurore Aubail, Jonas Teilmann, Rune Dietz, Frank Rigét, Tero Harkonen, \\ Olle Karlsson, Aqqalu Rosing-Asvid, Florence Caurant
}

\section{To cite this version:}

Aurore Aubail, Jonas Teilmann, Rune Dietz, Frank Rigét, Tero Harkonen, et al.. Investigation of mercury concentrations in fur of phocid seals using stable isotopes as tracers of trophic levels and geographical regions. Polar Biology, 2011, 34 (9), pp.1411-1420. 10.1007/s00300-011-0996-z . hal00611657

\section{HAL Id: hal-00611657 \\ https://hal.science/hal-00611657}

Submitted on 26 Jul 2011

HAL is a multi-disciplinary open access archive for the deposit and dissemination of scientific research documents, whether they are published or not. The documents may come from teaching and research institutions in France or abroad, or from public or private research centers.
L'archive ouverte pluridisciplinaire HAL, est destinée au dépôt et à la diffusion de documents scientifiques de niveau recherche, publiés ou non, émanant des établissements d'enseignement et de recherche français ou étrangers, des laboratoires publics ou privés. 
Investigation of mercury concentrations in fur of phocid seals using stable isotopes as tracers of trophic levels and geographical regions

Aurore Aubail $^{\mathrm{a}, \mathrm{b}, *}$, Jonas Teilmann ${ }^{\mathrm{a}}$, Rune Dietz ${ }^{\mathrm{a}}$, Frank Rigét ${ }^{\mathrm{a}}$, Tero Harkonen ${ }^{\mathrm{c}}$, Olle Karlsson ${ }^{\mathrm{c}}$, Aqqalu Rosing-Asvid ${ }^{\mathrm{d}}$, Florence Caurant ${ }^{\mathrm{b}}$

${ }^{a}$ National Environmental Research Institute, Aarhus University, Frederiksborgvej 399, P.O. Box 358, DK-4000 Roskilde, Denmark

${ }^{\mathrm{b}}$ Littoral, Environnement et Sociétés (LIENSs), UMR 6250, CNRS-Université de La Rochelle, 2 rue Olympe de Gouges, F-17042 La Rochelle cedex, France

${ }^{\mathrm{c}}$ Department of Contaminant Research, Swedish Museum of Natural History, P.O. Box 50007, S-10405 Stockholm, Sweden

${ }^{\mathrm{d}}$ Greenland Institute of Natural Resources, P.O. Box 570, 3900 Nuuk, Greenland

* Corresponding author:

E-mail address: aaubail@yahoo.fr

Tel.: +33 546507629; Fax.: +33 546458264 


\begin{abstract}
Recent studies have shown that the complementary analysis of mercury $(\mathrm{Hg})$ concentrations and stable isotopic ratios of nitrogen $\left(\delta^{15} \mathrm{~N}\right)$ and carbon $\left(\delta^{13} \mathrm{C}\right)$ can be useful for investigating the trophic influence on the $\mathrm{Hg}$ exposure and accumulation in marine top predators. In this study, we propose to evaluate the interspecies variability of $\mathrm{Hg}$ concentrations in phocids from polar areas and to compare $\mathrm{Hg}$ bioaccumulation between both hemispheres. Mercury concentrations, $\delta^{15} \mathrm{~N}$ and $\delta^{13} \mathrm{C}$ were measured in fur from 85 individuals representing 7 phocidae species, a Ross seal (Ommatophoca rossii), Weddell seals (Leptonychotes weddellii), crabeater seals (Lobodon carcinophaga), harbour seals (Phoca vitulina), grey seals (Halichoerus grypus), ringed seals (Phoca hispida), and a bearded seal (Erignathus barbatus), from Greenland, Denmark and Antarctica. Our results showed a positive correlation between $\mathrm{Hg}$ concentrations and $\delta^{15} \mathrm{~N}$ values among all individuals. Seals from the Northern ecosystems displayed greater $\mathrm{Hg}$ concentrations, $\delta^{15} \mathrm{~N}$ and $\delta^{13} \mathrm{C}$ values than those from the Southern waters. Those geographical differences in $\mathrm{Hg}$ and stable isotopes values were likely due to higher environmental $\mathrm{Hg}$ concentrations and somewhat greater number of steps in Arctic food webs. Moreover, dissimilarities in feeding habits among species were shown through $\delta^{15} \mathrm{~N}$ and $\delta^{13} \mathrm{C}$ analysis, resulting in an important interspecific variation in fur $\mathrm{Hg}$ concentrations. A trophic segregation was observed between crabeater seals and the other species, resulting from the very specific diet of krill of this species and leading to the lowest observed $\mathrm{Hg}$ concentrations.
\end{abstract}

Key words: Hg, nitrogen, carbon, hair, Arctic, Antarctica 


\section{Introduction}

Mercury $(\mathrm{Hg})$ is a global contaminant released into the ecosystem from both natural and anthropogenic sources (Pacyna et al. 2006). The gaseous elemental form of this metal is very volatile, and once in the atmosphere, it can be transported from mid to high latitudes over long distances, and thereby reach the polar regions (Brooks et al. 2005). Although $\mathrm{Hg}$ is partly re-emitted to the air, it is accumulated in organisms and biomagnified in the trophic chain in polar ecosystems (Atwell et al. 1998; Bargagli et al. 1998). Thus, organisms feeding on species at high trophic levels generally show greater $\mathrm{Hg}$ concentrations than those feeding on species at lower trophic levels. Since marine mammals mainly are exposed to $\mathrm{Hg}$ through their diet (Aguilar et al. 1999), differences in foraging strategies and feeding habits among species may lead to differences in exposure to $\mathrm{Hg}$, resulting in interspecific disparities in concentrations of $\mathrm{Hg}$.

Biological factors like age, sex or physiological status are known to influence the diet, and thereby, the exposure and accumulation of $\mathrm{Hg}$ in many species. However, differences in $\mathrm{Hg}$ concentrations can also result from geographical or temporal variations in the environmental levels of $\mathrm{Hg}$. Whether differences in $\mathrm{Hg}$ concentrations among species result from differences in diet or environmental levels of $\mathrm{Hg}$ can be investigated by analysing naturally occurring variations in stable isotopes of nitrogen $\left({ }^{15} \mathrm{~N}\right.$ and $\left.{ }^{14} \mathrm{~N}\right)$ and carbon $\left({ }^{13} \mathrm{C}\right.$ and ${ }^{12} \mathrm{C}$ ) (Hobson and Welch 1992). The underlying principle is that ratios of heavier $v s$ lighter isotopes of nitrogen and carbon in tissues of predators can be traced to those of their prey as these two elements are assimilated through the diet. Consumer tissues are stepwise enriched in ${ }^{15} \mathrm{~N}$ relative to those of their prey, and consequently, $\delta^{15} \mathrm{~N}$ measurements can be used to determine the trophic position of organisms (Minagawa and Wada 1984). In contrast, $\delta^{13} \mathrm{C}$ values vary little through the food chain $(<1 \%)$, and can thus help to determine the source of carbon used by primary consumers in a food web, and provide information on the foraging habitat of the studied organisms (Fry and Sherr 1984). Furthermore, turn over rates of stable isotopes in tissues vary with the metabolic rate of the tissue (Tieszen et al. 1983), and isotopic analyses can give information on feeding habits over the last days, weeks, months or years, depending on which tissue types are analysed.

Phocid seals are long-lived marine mammals at the top of food chains in polar ecosystems. Using stable isotopes of nitrogen and carbon as tracers of the trophic level and habitat use respectively, we investigated if concentrations of $\mathrm{Hg}$ in seal species from different geographical areas could be used to determine the trophic levels they prey upon. We studied a Ross seal (Ommatophoca rossii), Weddell seals (Leptonychotes weddellii) and crabeater seals (Lobodon carcinophaga) from 
Antarctic regions, harbour seals (Phoca vitulina) and grey seals (Halichoerus grypus) found throughout coastal regions of the Northern hemisphere, and ringed seals (Phoca hispida) and a bearded seal (Erignathus barbatus), which both show Northern circumpolar distributions (Reeves et al. 1992).

While the Ross seal has a varied diet based on squid, fish and krill, and the Weddell seal mainly feeds on fish, but also on various cephalopods and crustaceans, the crabeater seal is specialised on feeding almost exclusively on Antarctic krill (Bowen et al. 2002). In the Northern hemisphere, harbour and grey seals feed on a wide range of organisms, pelagic and benthic fish, cephalopods and crustaceans (Reeves et al. 1992). Finally, ringed seals are believed to feed mainly on a variety of fish and invertebrates such as amphipods, euphausiids and cephalopods, while the bearded seal consumes mainly benthic invertebrates, i.e. clams, crustaceans, cephalopods as well as some fish (Reeves et al. 1992). Pauly et al. (1998) estimated the trophic levels of several marine mammals mainly by stomach content analysis. Values for trophic levels ranged from 3.3 for the crabeater seal to 4.1 for the Ross seal. Estimated values were 3.4 for bearded seals, 3.8 for ringed seals, harbour seals and grey seals, whereas it was estimated at 4.0 for Weddell seals.

Soft tissues are commonly used for analysis of metals and stable isotopes. However, fur provides a non-invasive way to investigate metals and stable isotopes of seals. Fur is keratin-based containing records of metallic and isotopic elements which are deposited there during the annual moult. Mercury is one of the trace elements transported to the fur follicles via the blood supply (Ikemoto et al. 2004), and subsequently incorporated into the hair during periods of growth (Brookens et al. 2007). Hair is widely used as an indicator of blood $\mathrm{Hg}$ levels for mammals, and particularly for humans, and has been used as an indicator of exposure to the environmental pollution also in pinnipeds (Brookens et al. 2007; Gray et al. 2008; Ikemoto et al. 2004; Medvedev et al. 1997; Watanabe et al. 1996; Wenzel et al. 1993; Yamamoto et al. 1987).

The purpose of this study was to determine $\mathrm{Hg}$ concentrations in the fur of seven species of phocid seals from different geographical areas, and to evaluate the influence of biological factors in the bioaccumulation process. Stable isotope analyses were used to evaluate differences or similarities in the diet or in the foraging habitat among species that could explain variations in $\mathrm{Hg}$ concentrations. We also evaluated if fur can be used for monitoring of $\mathrm{Hg}$ in phocid seals in the future. 


\section{Materials and methods}

\section{Sampling procedure and preparation}

Hair samples of 85 seals were obtained from seven phocid seal species, i.e. Ross seal, Weddell seal, crabeater seal, harbour seal, grey seal, ringed seal, and bearded seal. The samples were collected from three distinct geographical areas, Ross Sea, Antarctica (Ant), Denmark (Dk), and Greenland (Gr) (cf. Fig. 1). Samples were taken in the period 1996 - 2009. Length and weight of the animals were recorded, and age was estimated visually based on size and fur colour, according to three classes (yearling, juvenile and adult). Number of individuals, estimated age and gender are summarised for each species in Table 1.

Samples were stored in polyethylene plastic bags and kept at $-20^{\circ} \mathrm{C}$. Prior to analysis, fur samples were washed in a diluted standard detergent (RBS 35; Bie \& Berntsen A/S, Denmark). Subsequently, the hair samples were rinsed in several ultra-pure Milli-Q water baths, and dried for 24 hours at room temperature.

\section{Analytical procedures, instrumentation and quality assurance for $\mathrm{Hg}$ measurements}

The $\mathrm{Hg}$ measurements were performed at the laboratory of the National Environmental Research Institute in Roskilde, Denmark, using a solid sample atomic absorption spectrometer AMA-254 (Advanced Mercury Analyser-254 from LECO, Sweden). A homogenised subsample of 5 to $10 \mathrm{mg}$ of fur was analysed from each individual. The use of this apparatus does not require chemical pretreatment, which reduces risks for contamination or loss of $\mathrm{Hg}$. The analytical process consists of a drying period at $120^{\circ} \mathrm{C}$ prior to a combustion phase at $750^{\circ} \mathrm{C}$, which leads to desorption of $\mathrm{Hg}$ from the samples. The $\mathrm{Hg}$ vapour produced is subsequently carried by an oxygen flow to a gold amalgamator, and trapped on its surface. The collected $\mathrm{Hg}$ is thereafter released from the amalgamator by a short heat-up to $900^{\circ} \mathrm{C}$, and carried in a pulse through a spectrophotometer, where $\mathrm{Hg}$ is measured by UV absorption. The operating times used for this study, i.e. drying, decomposition, and waiting time, were 30,150 , and $45 \mathrm{~s}$, respectively. The instrument is described in detail elsewhere (Hall and Pelchat 1997).

The accuracy and reproducibility of the method were tested by including human hair (IAEA-086) reference material at the beginning and at the end of the analysis cycle, and by running it every 10 samples. Results of quality controls showed a good precision with a relative standard deviation of $3.9 \%$. The accuracy was $96 \%$ of the assigned concentration $(n=9)$. The National Environmental Research Institute participates in the international inter-laboratory comparison exercises conducted 
by the EEC (QUASIMEME), and showed satisfactory results in the latest test in 2007 for the AMA$254(0<\mathrm{z}<0.5)$. All data are presented on a dry weight basis $(\mathrm{dw})$ and the detection limit is 0.1 ng. $\mathrm{g}^{-1} \mathrm{dw}$.

\section{Analytical procedures and instrumentation for stable isotope measurements}

A homogenised aliquot of approximately $0.5 \mathrm{mg}$ of hair from each individual was weighted and loaded into tin capsules.

Relative abundances of stable isotopes of carbon $\left(\delta^{13} \mathrm{C}\right)$ and nitrogen $\left(\delta^{15} \mathrm{~N}\right)$ were determined using an elemental analyser (Flash EA 1112 fitted with a "No Blank" option, Thermo Scientific, Milan, Italy) coupled to an isotope ratio mass spectrometer (Delta V Advantage with a Conflo IV interface, Thermo Scientific, Bremen, Germany). Stable isotope results are expressed in delta notation $(\delta)$, defined as the part per thousand (\%o) deviation from a standard material:

$\delta^{13} \mathrm{C}$ or $\delta^{15} \mathrm{~N}=[($ Rsample / Rstandard $)-1] \times 10^{3}$,

where Rsample and Rstandard are the fractions of heavy to light isotopes in the sample and standard, respectively. The international standards are the Pee Dee Belemnite (PDB) marine fossil limestone formation from South Carolina for $\delta^{13} \mathrm{C}$, and atmospheric nitrogen for $\delta^{15} \mathrm{~N}$.

The analytical precision of the measurements was $<0.06 \%$ for carbon and $<0.1 \%$ for nitrogen, based on replicate measurements of acetanilide as internal laboratory reference material.

\section{Statistical analysis}

Prior to the statistical analyses, the $\mathrm{Hg}$ data were log-transformed (base e) to reduce skewness and fit parametric requirements. Shapiro-Wilk and Bartlett test were applied to test the assumptions of parametric tests, such as analysis of variance (ANOVA) and linear regression analysis. In few cases, the assumptions were not fulfilled because of a couple of high $\mathrm{Hg}$ concentration values. However, ANOVA tests are robust to small deviations of the data from the normal distribution (Zar 2009).

Standard parametric tests such linear regression analysis and analysis of variance, were applied to test for the influence of factors (i.e. age category, sex, species and region of sampling) on the logtransformed $\mathrm{Hg}$ concentrations or $\delta^{13} \mathrm{C}$ and $\delta^{15} \mathrm{~N}$ values. If the first runs of ANOVA test showed no significance of the interaction between two factors, the interaction factor was removed and the test re-run. Tukey HSD (Honestly Significant Difference) test was used as a posterior ANOVA test to determine which means were significantly different from one another. Wilcoxon tests were used to 
test for differences in log-transformed $\mathrm{Hg}$ concentrations or stable isotope ratios between two species from the same region or among individuals from the same species originating from two regions. Non-parametric test Spearman rank correlation were used to test the relationships between $\mathrm{Hg}$ concentrations, $\delta^{13} \mathrm{C}$ and $\delta^{15} \mathrm{~N}$ values.

The number of individuals was low for some of the species, and only crabeater seals, Weddell seals and ringed seals were represented by more than 10 individuals (Table 1). All species (7 species, 85 individuals) are shown on the graphs, but the bearded seal $(n=1)$ and the Ross seal $(n=1)$ are excluded from statistical analyses due to low sample size.

The significance level was set to $\mathrm{p}=0.05$.

The statistical analyses were performed using the free software R, version 2.1.1 (R Development Core Team 2008). 


\section{Results}

\section{Hg concentrations and stable isotope ratios}

Mercury concentrations in the hair ranged from $0.07 \mu \mathrm{g} \cdot \mathrm{g}^{-1} \mathrm{dw}$ for the crabeater seal to $30.6 \mu \mathrm{g} . \mathrm{g}^{-1}$ $\mathrm{dw}$ for the harbour seal, and mean concentrations increased in the sequence: crabeater seals < Ross seal $<$ bearded seal $<$ Weddell seals $<$ ringed seals $<$ harbour seals $(D k)<$ grey seals $<$ harbour seals (Gr) (Table 2). Nitrogen stable isotopic ratios in hair of the different seal species varied from 6.02\%o for the crabeater seals to $19.33 \%$ for the ringed seals (crabeater seals < Ross seal $<$ Weddell seals $<$ bearded seal $<$ harbour seals $=$ grey seals $<$ ringed seals, for mean values), while $\delta^{13} \mathrm{C}$ values ranged from $-25.11 \%$ for the crabeater seals to $-15.06 \%$ for the harbour seals (crabeater seals < Weddell seals < Ross seal < grey seals < ringed seals < harbour seals $(\mathrm{Dk})<$ bearded seal < harbour seals (Gr), for mean values) (Table 2).

\section{Influence of sex and age classes}

Only adult individuals were selected to test the factor sex. However, the three categories of age (yearling, juvenile and adult) were not all well represented for each species (Table 1). Thus, the influence of sex on $\mathrm{Hg}$ concentrations was tested only on the crabeater seals, while the influence of age classes was tested on crabeater seals, Weddell seals and ringed seals.

No difference in $\mathrm{Hg}$ concentrations between genders was recorded among the crabeater seals (Oneway ANOVA, $\mathrm{F}=0.26 ; \mathrm{p}=0.62$ ). Figure 2 shows $\mathrm{Hg}$ levels for the different age classes for crabeater seals, Weddell seals and ringed seals. Log-transformed $\mathrm{Hg}$ concentrations increased significantly with age for crabeater seals (One-way ANOVA, $F=221.1, p<0.001$ ), where adults showed a higher mean $\mathrm{Hg}$ concentration $\left(0.61 \mu \mathrm{g} \cdot \mathrm{g}^{-1} \mathrm{dw}\right)$ compared with juveniles $\left(0.11 \mu \mathrm{g} \cdot \mathrm{g}^{-1} \mathrm{dw}\right)$. However, no significant differences among age classes were found for Weddell seals $(\mathrm{F}=1.71, \mathrm{p}=$ $0.23)$ or ringed seals $(\mathrm{F}=2.7, \mathrm{p}=0.09)$.

The $\delta^{15} \mathrm{~N}$ and $\delta^{13} \mathrm{C}$ values also differed significantly among age groups for the crabeater seals (Oneway ANOVA, $\mathrm{F}=9.53, \mathrm{p}=0.004$ and $\mathrm{F}=113.3, \mathrm{p}<0.001$, respectively), with the adults of this species showing lower mean $\delta^{15} \mathrm{~N}$ and $\delta^{13} \mathrm{C}$ values \pm standard errors $(7.26 \pm 0.27 \%$, $-23.38 \pm$ $0.16 \%$, respectively, $\mathrm{n}=10)$ than the juvenile individuals $(7.89 \pm 0.07 \%$ o, $-24.67 \pm 0.04 \%$, respectively, $\mathrm{n}=23$ ) (Fig. 3). However, this difference in $\delta^{15} \mathrm{~N}$ and $\delta^{13} \mathrm{C}$ values between age groups was not significant for the Weddell seals $(F=0.65, p=0.55$ and $F=4.20, p=0.051$, respectively) and the ringed seals $(F=0.31, p=0.73$ and $F=1.30, p=0.29$, respectively). Age specific 
differences were not tested for in ringed seals due to small sample sizes in age groups yearlings and juveniles.

\section{Influence of the species and the geographical area}

The average $\mathrm{Hg}$ concentration increased in the sequence: crabeater seals (Ant), Ross seal (Ant), bearded seal (Gr), Weddell seals (Ant), ringed seals (Gr), harbour seals (Dk), grey seals (Dk), harbour seals (Gr) (Table 2). Highly significant differences between species were found for $\log$ transformed $\mathrm{Hg}$ concentrations (One-way ANOVA, $\mathrm{F}=84.73, \mathrm{p}<0.001$ ) and $\delta^{15} \mathrm{~N}$ and $\delta^{13} \mathrm{C}$ values ( $\mathrm{F}=648.8, \mathrm{p}<0.001$ and $\mathrm{F}=537, \mathrm{p}<0.001$, respectively), with the crabeater seal showing the lowest $\mathrm{Hg}, \delta^{15} \mathrm{~N}$ and $\delta^{13} \mathrm{C}$ values of all species (Fig. 4A/B). Tukey HSB tests showed that crabeater seals had significantly lower $\mathrm{Hg}$ concentrations compared with the other species, and that $\mathrm{Hg}$ concentrations in hair of harbour seals were significantly greater than in Weddell seals and ringed seals (Table 2, Fig. 4A). Moreover, the $\delta^{15} \mathrm{~N}$ values differed among the species, except for between harbour seals and grey seals (Table 2, Fig. $4 \mathrm{~A}$ ) while $\delta^{13} \mathrm{C}$ values also varied among the species except for between ringed seals and grey seals (Table 2, Fig. 4B).

No significant difference was found for $\mathrm{Hg}$ (Wilcoxon, $\mathrm{W}=6, \mathrm{p}=0.7), \delta^{15} \mathrm{~N}(\mathrm{~W}=6, \mathrm{p}=0.7$ ) and $\delta^{13} \mathrm{C}(\mathrm{W}=6, \mathrm{p}=0.7)$ contents in hairs between harbour seals from Denmark and Greenland; however, it is worth noticing that the number of individuals was low and age groups were not comparable. Significant differences were found for $\mathrm{Hg}, \delta^{15} \mathrm{~N}$ and $\delta^{13} \mathrm{C}$ values in hair from seals collected in the three regions. Subsequent Tukey tests revealed that Antarctic seals had lower values of $\mathrm{Hg}, \delta^{15} \mathrm{~N}$ and $\delta^{13} \mathrm{C}$ while there were no significant differences between Greenland and Denmark (Table 2, Fig. 4). Significant correlations were also found between log-transformed $\mathrm{Hg}$ concentrations and $\delta^{15} \mathrm{~N}$ values (Spearman's correlation, $\rho=0.68, \mathrm{p}<0.001$, Fig. 4A, $\mathrm{y}=0.133 \mathrm{x}-$ 1.673), log-transformed $\mathrm{Hg}$ and $\delta^{13} \mathrm{C}$ values $(\rho=0.83, \mathrm{p}<0.001$, Fig. $4 \mathrm{~B}, \mathrm{y}=0.168 \mathrm{x}+3.514)$, and $\delta^{15} \mathrm{~N}$ and $\delta^{13} \mathrm{C}$ values $(\rho=0.76, p<0.001$, Fig. $4 \mathrm{C}, \mathrm{y}=1.064 \mathrm{x}+34.835)$ including all species. 


\section{Discussion}

\section{Influence of sex and age groups on Hg concentrations in fur}

The influence of gender on $\mathrm{Hg}$ concentrations varies among studies and species. Thus, a study carried out on fur from Baikal seals Phoca sibirica showed no difference in $\mathrm{Hg}$ concentrations between genders (Watanabe et al. 1996), whereas Wenzel et al. (1993) observed higher levels and a greater variability in $\mathrm{Hg}$ concentrations in fur from female compared to male harbour seals. In the same way, greater concentrations of $\mathrm{Hg}$ were found in fur from adult male Pacific harbour seals Phoca vitulina richardii and leopard seals Hydrurga leptonyx as compared with females in both species (Brookens et al. 2007; Gray et al. 2008). Gender specific differences in Hg concentrations could be the result of sexual dimorphism or dissimilarities in dietary intake or dietary preferences between male and female seals. This could be partially linked to the different energy requirement for gestation and lactation. Crabeater seals do not show any marked sexual dimorphism (Shirihai 2007), and no significant differences for $\mathrm{Hg}$ concentrations between male and female crabeater seals were found, which would be consistent with comparable exposure for both genders in this species.

Concentrations of $\mathrm{Hg}$ increased significantly with age in crabeater seals, but not for the Weddell seals or the ringed seals (Fig 2). Such age related differences have been previously reported for harbour seals (Brookens et al. 2007; Wenzel et al. 1993) and ringed seals (Medvedev et al. 1997). Increasing concentrations with age in our study likely result from a difference in foraging habits between juveniles and adults, which was confirmed by the significant difference in $\delta^{15} \mathrm{~N}$ and $\delta^{13} \mathrm{C}$ values among age classes detected for the crabeater seals (Fig. 3). The greater variability of $\delta^{15} \mathrm{~N}$ values for the adults compared to the juvenile crabeater seals suggests that older individuals feed on a wider range of prey than younger seals. In addition, the distinct $\delta^{13} \mathrm{C}$ values displayed by the juvenile individuals and the adults indicate that they have different feeding habitats. Since $\delta^{13} \mathrm{C}$ values are generally greater in benthic or sea-ice algae than in pelagic algae (Fry and Sherr 1984; Tamelander et al. 2006), our results, with significantly lower $\delta^{13} \mathrm{C}$ values in the juveniles, suggest that juvenile individuals may forage mainly krill in the water column. Previous findings indicate that despite the high degree of specialisation of this species on a single prey resource, i.e. krill, crabeater seals have the behavioural plasticity to forage successfully under a wide range of environmental conditions, for example, at varying depths and duration of dives and selecting prey in a greater panel if necessary (Burns et al. 2004). Similarly to our study, higher $\delta^{13} \mathrm{C}$ values have 
previously been observed in adult and subadult crabeater seals compared to juveniles and pups by Zhao et al. (2004), though no statistical difference between age classes was found in that study.

Differences in diving and foraging behaviour between adults and juveniles, and ontogenetic shifts in diet have previously been documented in several species of phocid seals (Born et al. 2004; Burns et al. 1998; Holst et al. 2001; Lowry et al. 1980; Reeves et al. 1992). Generally, newly weaned pups forage less efficiently and have more limited diving capacity compared with older seals, leading to differences in diet (Holst et al. 2001; Reeves et al. 1992). Similarly to crabeater seals, distinct $\delta^{13} \mathrm{C}$ values were observed between juvenile and adult individuals of ringed seals and Weddell seals, suggesting that juvenile seals of those species tend to explore different foraging habitats than the adults. One such example is the dichotomy among Weddell seal yearlings, where some individuals predominantly feed on benthic species in shallow waters, whereas others mainly forage in the same deep-water pelagic zone as the adults do (Burns et al. 1998).

\section{Differences among geographical areas and species (feeding strategies)}

Phocid seals renew their fur once a year over a relatively short period, the annual moult, which occurs at different times of year depending on species (Berta 2002). The hair grows rapidly and discontinuously, and concentrations of $\mathrm{Hg}$ measured in the hair reflect the availability of $\mathrm{Hg}$ to the growing pile via blood during the annual moult (Berlin 1979). Most seals moult within a twomonths period (Stutz 1967), and Hg concentrations in fur result from the diet composition during or prior to the moulting period. In addition, the moulting period occurs from late spring to late summer in both hemispheres. As a result, months during which it occurs differ, and species from the Northern hemisphere tend to moult between May and September, whereas species from the Southern hemisphere moult between December and February (Reeves et al. 1992; Shirihai 2007). Thus, seasonal variations in the origin of $\mathrm{Hg}$, its long-range atmospheric transport and its deposition -including Mercury Depletion Events or MDEs which have been shown to occur at the respective springtime in both Arctic (Schroeder et al. 1998) and Antarctica (Ebinghaus et al. 2002)-, may have a great influence on the $\mathrm{Hg}$ exposure and bioaccumulation in the seals.

Levels of $\mathrm{Hg}$ concentrations in fur of species from Antarctica did not exceed $3.5 \mu \mathrm{g} . \mathrm{g}^{-1} \mathrm{dw}$ which was relatively low compared to those from Greenland and Denmark, and earlier studies of Hg levels in hair from Antarctic pinnipeds have not reported concentrations exceeding $11 \mu \mathrm{g} \cdot \mathrm{g}^{-1} \mathrm{dw}$ (Gray et al. 2008; Yamamoto et al. 1987). Although this difference can be related to the fact that the various species have different feeding habits, the global distribution pattern of released $\mathrm{Hg}$ may also contribute to those differences in $\mathrm{Hg}$ concentrations observed in seals from the Northern and the Southern hemispheres. Indeed, the total deposition pattern of $\mathrm{Hg}$ (dry and wet deposition) in the 
2000's shows that concentrations of $\mathrm{Hg}$ are much lower in the Southern hemisphere than in the Northern hemisphere (AMAP/UNEP 2008).

The variation in stable isotopic values between species from Northern and Southern polar ecosystems could likely reflect geographical differences in the $\delta^{15} \mathrm{~N}$ and $\delta^{13} \mathrm{C}$ values at the base of food webs. Phocid seals from Northern ecosystems generally show greater $\delta^{15} \mathrm{~N}$ values and significantly greater $\delta^{13} \mathrm{C}$ values than those from Southern waters (Fig. 4). However, $\delta^{15} \mathrm{~N}$ values reported for producers do not differ between both hemispheres. Horton et al. (2009) determined a mean value of approximately 6.5\% (range between 4 and $8 \%$ ) for phytoplankton and 6\%o for ice algae (range between 4 and 7\%o) from different studies carried out in the Arctic. Mincks et al. (2008) reported similar mean values in the West Antarctic Peninsula Shelf, ranging from 3.3 to $7.5 \%$ for phytoplankton and from 4.5 and $6 \%$ for ice algae. Thus, the $\delta^{15} \mathrm{~N}$ values found in our study would imply a greater number of steps in the Arctic food web and thus higher trophic levels for seals. Earlier studies have shown that $\mathrm{Hg}$ concentrations in biota increase with the trophic levels (i.e. $\delta^{15} \mathrm{~N}$ values), i.e. predators feeding on high trophic levels usually show higher $\mathrm{Hg}$ concentrations than those feeding on lower levels (Atwell et al. 1998; Campbell et al. 2005). The biomagnification of $\mathrm{Hg}$ in the food web is also demonstrated in our study by the greater $\mathrm{Hg}$ concentrations as well as $\delta^{15} \mathrm{~N}$ values exhibited by the Northern hemisphere species.

Concerning carbon stable isotopes ratios, Rau et al. (1982) reported distinct latitudinal trends in plankton $\delta^{13} \mathrm{C}$ between the Northern and Southern oceans, with $\delta^{13} \mathrm{C}$ values of the Southern ocean decreasing more and faster toward the South Pole than toward the North Pole. The isotopic results of our study illustrate these latitudinal variations of $\delta^{13} \mathrm{C}$ values between Northern and Southern oceans, the phocid seal species from Antarctic waters showing lower $\delta^{13} \mathrm{C}$ values of approximately 4\% relative to the Arctic species (Table 2). In addition, some of the variations in $\delta^{13} \mathrm{C}$ values could also be due to the influence of the different foraging habitats of the species, which imply various carbon sources, i.e. pelagic, sympagic or benthic. It seems indeed that the sympagic or iceassociated algae, which exhibits approximately mean $\delta^{13} \mathrm{C}$ values of -20 to $-18 \%$ in both polar regions (see review in Horton et al. 2009; Mincks et al. 2008) would influence more the $\delta^{13} \mathrm{C}$ values of the Arctic seals (mean value of $-16.95 \pm 0.94 \%$ (sd)), and especially the ringed seals, than the Antarctic ones $(-23.95 \pm 0.81 \%$ o). Thus, it would indicate a greater participation of the Northern species in the sympagic food web than the Southern ones. As a result, according to the type of food web and prey species on which seals feed, the $\mathrm{Hg}$ exposure and bioaccumulation would be different. 
Thus, the sequence of $\mathrm{Hg}$ impregnation was harbour seal > grey seal > ringed seal > bearded seal > Weddell seal > Ross seal > crabeater seal, which may reflect the influence of differences in diet of these species. The crabeater seal showed the lowest $\mathrm{Hg}\left(0.26 \pm 0.04 \mu \mathrm{g}^{\left.-g^{-1} \mathrm{dw}\right)}\right.$ and $\delta^{15} \mathrm{~N}$ values $(7.70 \pm 0.11 \%$ ) in fur of all investigated seals, which is the result of its very specific diet, almost entirely composed of krill (Bowen et al. 2002). Of the three species from the Southern Ocean, the Weddell seal exhibited the greatest $\mathrm{Hg}$ concentration $\left(2.09 \pm 0.21 \mu \mathrm{g} . \mathrm{g}^{-1} \mathrm{dw}\right)$ and $\delta^{15} \mathrm{~N}$ value (13.46 $\pm 0.21 \%$ ). These high values reflect its diet consisting of pelagic fish, which are believed to be the predominant prey items of the Weddell seal in McMurdo Sound, near our sampling area, although this species has also been reported feeding on cephalopods and crustaceans (Burns et al. 1998).

Among the phocid seal species from the Northern hemisphere, harbour seals had greater Hg levels than ringed seals, although a bit lower $\delta^{15} \mathrm{~N}$ values were found in ringed seals (Table 2). Harbour seals and ringed seals are small pinnipeds, feeding on a large variety of organisms, including fish, cephalopods and various crustaceans (Reeves et al. 1992). Pauly et al. (1998) reported the harbour seal being on a slightly higher trophic level $(\mathrm{TL}=4)$ than the ringed seal $(\mathrm{TL}=3.8)$. Our sample of Greenlandic harbour seals consisted of adults whereas ringed seals from Greenlandic waters were mainly represented by yearlings. The elevated $\delta^{15} \mathrm{~N}$ values showed by the ringed seals in our study $(17.64 \pm 0.18 \%$ o $)$ may be caused by the fact that the diet of yearlings partly included milk, which would give this pattern, as also found for Steller sea lions (Eumetopias jubatus) (Hobson and Sease 1998). This maternal input to ringed seal yearlings is supported by the greater $\delta^{15} \mathrm{~N}$ values displayed by this age group compared to the adult one. Similarly, the greater $\mathrm{Hg}$ concentrations in adult harbour seals could result from that they feed on larger prey with greater burdens of $\mathrm{Hg}$ than ringed seal yearlings.

No significant difference in $\mathrm{Hg}$ concentrations, $\delta^{15} \mathrm{~N}$ or $\delta^{13} \mathrm{C}$ values was found between harbour seals and grey seals from Danish waters, which is in concordance with results from Pauly et al. (1998), who estimated both species to the same trophic level at 4. The grey seal feeds on schooling fish, squid, cephalopods and occasionally sea birds (Barros and Clarke 2002), and a great variability in both $\mathrm{Hg}$ concentrations and stable isotopic ratio values was observed for this species, reflecting a wide range of prey from various foraging areas, but likely also the low sample size.

Finally, no significant difference was found in $\mathrm{Hg}$ contents in hair among harbour seals from Greenlandic and Danish waters, but the sample size was small for this species, and samples from Greenland and Denmark were not comparable since the Greenlandic sample of harbour seals consisted of adults, whereas the Danish sample was composed of a yearling and juvenile animals. However, whereas all individuals showed similar $\delta^{15} \mathrm{~N}$ values, suggesting a more or less similar diet, greater $\delta^{13} \mathrm{C}$ values found in the Greenlandic harbour seals compared to Danish ones, may 
reflect either a difference in the foraging strategy, related to the age dissimilarity, or a difference in the isotopic carbon signature of the two geographical areas. Furthermore, this difference could also highlight the influence of the ice-associated producers on the Greenlandic seals $\delta^{13} \mathrm{C}$ values, as shown by the greater $\delta^{13} \mathrm{C}$ value of ice algae compared to the phytoplankton one (Horton et al. 2009; Tamelander et al. 2006). The greater $\delta^{13} \mathrm{C}$ values of the Greenlandic harbour seals compared to those from Danish waters may thus underline the role of the sympagic food web in the Arctic marine ecosystem. 


\section{Conclusion}

This study showed consistent variations in $\mathrm{Hg}$ concentrations and $\delta^{15} \mathrm{~N}$ and $\delta^{13} \mathrm{C}$ values among species and geographical regions. This demonstrates that fur is a good tissue for monitoring exposure to $\mathrm{Hg}$ in phocid seals and for reconstructing their exposure history through their diet, especially with the non-destructive and invasive sampling protocols relative to this tissue. The significant correlation between $\mathrm{Hg}$ concentrations and $\delta^{15} \mathrm{~N}$ values highlighted the biomagnification of $\mathrm{Hg}$ in the food webs. The comparison of both hemispheres showed the greater $\mathrm{Hg}$ concentrations in the Northern one, which would be the result of a greater contamination and /or somewhat longer food chains in the Arctic. Our study confirmed the tight link between $\mathrm{Hg}$ exposure and feeding habits (as revealed by $\delta^{15} \mathrm{~N}$ and $\delta^{13} \mathrm{C}$ values) of seals. Thus, measurements of $\mathrm{Hg}$ contents in organisms in an ecosystem can provide information on the trophic levels of species and age groups. In the most optimal way, $\mathrm{Hg}$ analysis should be combined with isotopic tracers, although the seasonal and vertical variations in $\delta^{15} \mathrm{~N}$ and $\delta^{13} \mathrm{C}$ values in the water column and with latitudes may somehow introduce a bias in the interpretation of the results. The use of these analytical tools contributes to a better understanding of local ecosystem functions permitting investigations of partitioning of habitat use and trophic levels of similar species co-existing within the same ecosystem.

\section{Acknowledgements}

We would like to thank all the people who helped collecting the samples in the field, especially the crew of the Swedish icebreaker "Oden" who skilfully managed to find the seals and manoeuvre through the dense pack ice around Antarctica. Special acknowledgement to Carine Churlaud from the Centre Commun d'Analyses (La Rochelle, France) for her valuable input on the Hg analysis, and to Pierre Richard and Gaël Guillou from LIENSs (UMR 6250 CNRS-La Rochelle University, France) for their contribution and advice on the stable isotope analysis. This study was financed by The Dancea Programme, KVUG (Kommissionen for Videnskabelige Undersøgelser i Grønland), the Swedish Research Council, the Swedish Polar Institute, the Poitou-Charentes region and the M.L. Furnestin-Faure foundation. Finally, we also thank Travis Horton, Liying Zhao and a third anonymous reviewer for their contribution to this manuscript through their relevant comments. 


\section{References}

Aguilar A, Borrell A, Pastor T (1999) Biological factors affecting variability of persistent pollutant levels in cetaceans. J Cetacean Res Manag Special Issue 1:83-116

AMAP/UNEP (2008) Technical Background Report to the Global Atmospheric Mercury Assessment. Arctic Monitoring and Assessment Programme / UNEP Chemicals Branch. 159 pp

Atwell L, Hobson KA, Welch HE (1998) Biomagnification and bioaccumulation of mercury in an arctic marine food web: insights from stable nitrogen isotope analysis. Can J Fish Aquat Sci $55: 1114-1121$

Bargagli R, Monaci F, Sanchez-Hernandez JC, Cateni D (1998) Biomagnification of mercury in an Antarctic marine coastal food web. Mar Ecol Prog Ser 169:65-76

Barros NB, Clarke MR (2002) Diet. In: Perrin WF, Würsig B, Thewissen JGM (eds) Encyclopedia of marine mammals. Academic Press, pp 323-327

Berlin M (1979) Mercury. In: Frigberg L, Nordberg G, Vouk VB (eds) Handbook on the toxicology of metals. Elsevier, Amsterdam, pp 503-530

Berta A (2002) Pinnipedia, overview. In: Perrin WF, Würsig B, Thewissen JGM (eds) Encyclopedia of marine mammals. Academic Press, pp 903-911

Born EW, Teilmann J, Riget F (2004) Habitat Use of Ringed Seals (Phoca hispida) in the North Water Area (North Baffin Bay). Arctic 57, 129-142

Bowen WD, Beck CA, Austin DA (2002) Pinniped ecology. In: Perrin WF, Würsig B, Thewissen JGM. (eds) Encyclopedia of marine mammals. Academic Press, pp 911-921

Brookens TJ, Harvey JT, O'Hara TM (2007) Trace element concentrations in the Pacific harbor seal (Phoca vitulina richardii) in central and northern California. Sci Total Environ 372:676-692 
Brooks S, Lindberg S, Gordeev V, Christensen J, Gusev A, Macdonald R, Marcy S, Puckett K, Travnikov O, Wilson S (2005) Transport pathways and processes leading to environmental exposure. In: AMAP Assessment 2002: Heavy metals in the Arctic. Arctic Monitoring and Assessment Programme (AMAP), Oslo, pp 11-41

Burns JM, Trumble SJ, Castellini MA, Testa JW (1998) The diet of Weddell seals in McMurdo Sound, Antarctica as determined from scat collections and stable isotope analysis. Polar Biol 19:272-282

Burns JM, Costa DP, Fedak MA, Hindell MA, Bradshaw CJA, Gales NJ, McDonald B, Trumble SJ, Crocker DE (2004) Winter habitat use and foraging behavior of crabeater seals along the Western Antarctic Peninsula. Deep-Sea Res Pt II 51:2279-2303

Campbell LM, Norstrom RJ, Hobson KA, Muir DCG, Backus S, Fisk AT (2005) Mercury and other trace elements in a pelagic Arctic marine food web (Northwater Polynya, Baffin Bay). Sci Total Environ 351:247-263

Ebinghaus R, Kock HH, Temme C, Einax JW, Löwe AG, Richter A, Burrows JP, Schroeder WH (2002) Antarctic springtime depletion of atmospheric mercury. Environ Sci Technol 36:1238-1244

Fry B, Sherr EB (1984) $\delta^{13} \mathrm{C}$ Measurements As Indicators of Carbon Flow in Marine and FreshWater Ecosystems. Contrib Mar Sci 27:13-47

Gray R, Canfield P, Rogers T (2008) Trace element analysis in the serum and hair of Antarctic leopard seal, Hydrurga leptonyx, and Weddell seal, Leptonychotes weddellii. Sci Total Environ 399:202-215

Hall GEM, Pelchat P (1997) Evaluation of a direct solid sampling atomic absorption spectrometer for the trace determination of mercury geological samples. Analyst 122 (9):921-924

Hobson KA, Welch HE (1992) Determination of Trophic Relationships Within A High Arctic Marine Food Web Using $\delta^{13} \mathrm{C}$ and $\delta^{15} \mathrm{~N}$ Analysis. Mar Ecol Prog Ser 84:9-18

Hobson KA, Sease JL (1998) Stable isotope analyses of tooth annuli reveal temporal dietary records: An example using steller sea lions. Mar Mamm Sci 14:116-129 
Holst M, Stirling I, Hobson KA (2001) Diet of ringed seals (Phoca hispida) on the east and west sides of the North Water Polynya, northern Baffin Bay. Mar Mamm Sci 17:888-908

Horton TW, Blum JD, Xie Z, Hren M, Chamberlain CP (2009) Stable isotope food-web analysis and mercury biomagnification in polar bears (Ursus maritimus). Polar Res 28:443-454

Ikemoto T, Kunito T, Watanabe I, Yasunaga G, Baba N, Miyazaki N, Petrov EA, Tanabe S (2004) Comparison of trace element accumulation in Baikal seals (Pusa sibirica), Caspian seals (Pusa caspica) and northern fur seals (Callorhinus ursinus). Environ Pollut 127:83-97

Lowry LF, Frost KJ, Burns JJ (1980) Variability in the Diet of Ringed Seals, Phoca hispida, in Alaska. Can J Fish Aquat Sci 37:2254-2261

Medvedev N, Panichev N, Hyvarinen H (1997) Levels of heavy metals in seals of Lake Ladoga and the White Sea. Sci Total Environ 206:95-105

Minagawa M, Wada E (1984) Stepwise Enrichment of N-15 Along Food-Chains - Further Evidence and the Relation Between $\delta^{15} \mathrm{~N}$ and Animal Age. Geochim Cosmochim Ac 48:1135-1140

Mincks SL, Smith CR, Jeffreys RM, Sumida PYG (2008) Trophic structure on the West Antarctic Peninsula shelf: Detritivory and benthic inertia revealed by $\delta^{13} \mathrm{C}$ and $\delta^{15} \mathrm{~N}$ analysis. Deep-Sea Res Pt II 55:2502-2514

Pacyna EG, Pacyna JM, Steenhuisen F, Wilson S (2006) Global anthropogenic mercury emission inventory for 2000. Atmos Environ 40:4048-4063

Pauly D, Trites AW, Capuli E, Christensen V (1998) Diet composition and trophic levels of marine mammals. ICES J Mar Sci 55:467-481

R Development Core Team R (2008) A language and environment for statistical computing. Foundation for Statistical Computing, Vienna, Austria; ISBN 3-900051-07-0, URL http://www.Rproject.org 
Rau GH, Sweeney RE, Kaplan IR (1982) Plankton C-13/C-12 Ratio Changes with Latitude Differences Between Northern and Southern Oceans. Deep-Sea Res 29:1035-1039

Reeves RR, Stewart BS, Leatherwood S (1992) The Sierra Club Handbook of Seals and Sirenians. Sierra Club Books, San Francisco

Schroeder WH, Anlauf KG, Barrie LA, Lu JY, Steffen A, Schneeberger DR, Berg T (1998) Arctic springtime depletion of mercury. Nature 394:331-332

Shirihai H (2007) Seals. In: Kirwan GM (ed) A Complete Guide to Antarctic Wildlife - The Birds and Marine Mammals of the Antarctic Continent and the Southern Ocean, 2nd edn. A \& C Black, London, pp 332-354

Stutz SS (1967) Moult in Pacific Harbour Seal Phoca Vitulina Richardi. J Fish Res Board Can 24:435-441

Tamelander T, Renaud PE, Hop H, Carroll ML, Ambrose Jr WG, Hobson K (2006) Trophic relationships and pelagic-benthic coupling during summer in the Barents Sea Marginal Ice Zone revealed by stable carbon and nitrogen isotope measurements. Mar Ecol Prog Ser 310:33-46

Tieszen LL, Boutton TW, Tesdahl KG, Slade NA (1983) Fractionation and Turnover of Stable Carbon Isotopes in Animal-Tissues - Implications for $\delta^{13} \mathrm{C}$ Analysis of Diet. Oecologia 57:32-37

Watanabe I, Ichihashi H, Tanabe S, Amano M, Miyazaki N, Petrov EA, Tatsukawa R (1996) Trace element accumulation in Baikal seal (Phoca sibirica) from the Lake Baikal. Environ Pollut 94:169179

Wenzel C, Adelung D, Kruse H, Wassermann O (1993) Trace-Metal Accumulation in Hair and Skin of the Harbor Seal, Phoca-Vitulina. Mar Pollut Bull 26:152-155

Yamamoto Y, Honda K, Hidaka H, Tatsukawa R (1987) Tissue Distribution of Heavy-Metals in Weddell Seals (Leptonychotes weddellii). Mar Pollut Bull 18:164-169

Zar JH (2009) Biostatistical analysis: International edition. Pearson Education 
Zhao LY, Castellini MA, Mau TL, Trumble SJ (2004) Trophic interactions of Antarctic seals as determined by stable isotope signatures. Polar Biol 27:368-373 
Fig. 1 Map of the world showing the three geographical areas, Antarctica (Ant), Denmark (Dk), Greenland (Gr), of fur sampling of the phocid species

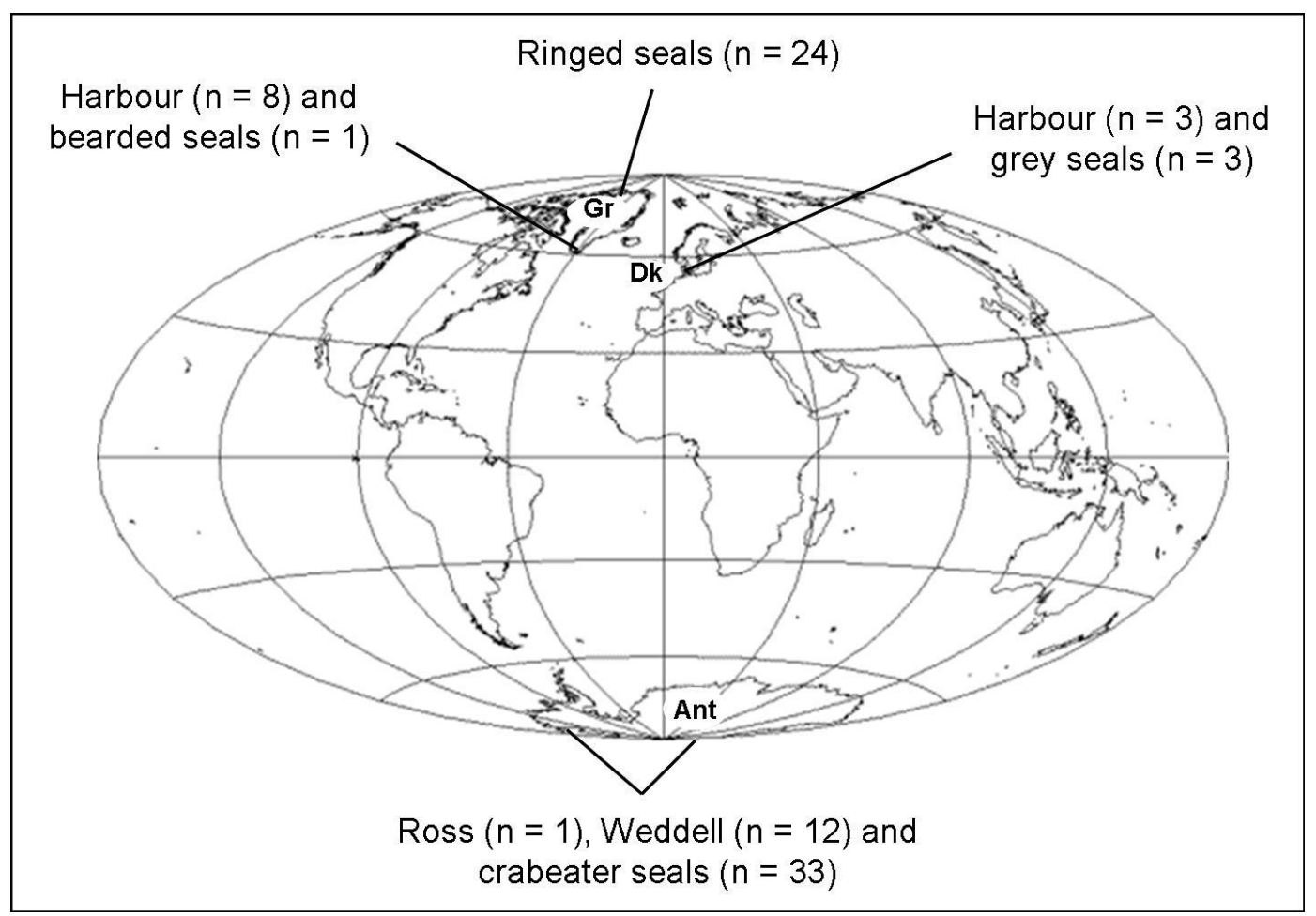


Fig. 2 Comparisons of $\mathrm{Hg}$ concentrations in fur (in $\mu \mathrm{g} / \mathrm{g} \mathrm{dw}$ ) among age classes for the Weddell seals, crabeater seals and ringed seals. The upper and lower hinges represent the quartiles, the vertical lines, the maximum and minimum data values and the bold line represents the median value while the points are outliers
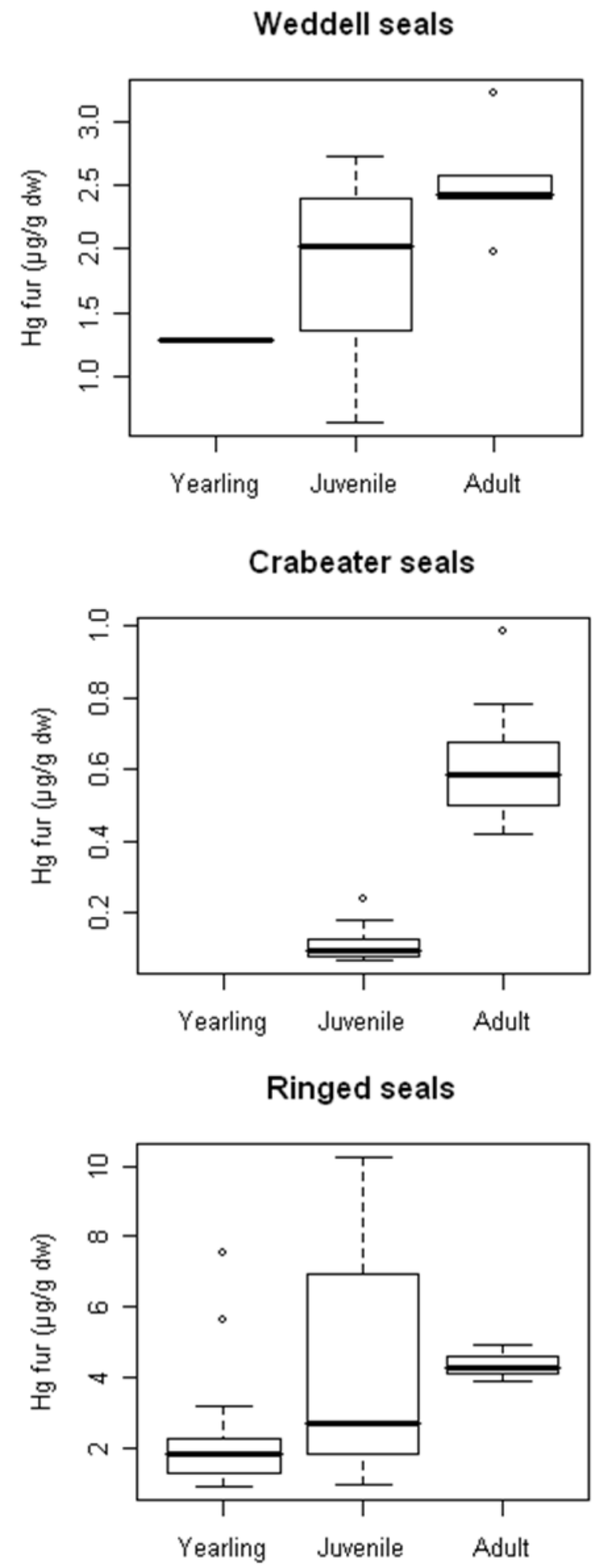
Fig. 3 Relations between $\delta^{15} \mathrm{~N}(\%) v s \delta^{13} \mathrm{C}(\%)$ values for the three age classes (filled circle = yearling, open circle $=$ juvenile, open triangle $=$ adult) for the Weddell seals, crabeater seals and ringed seals
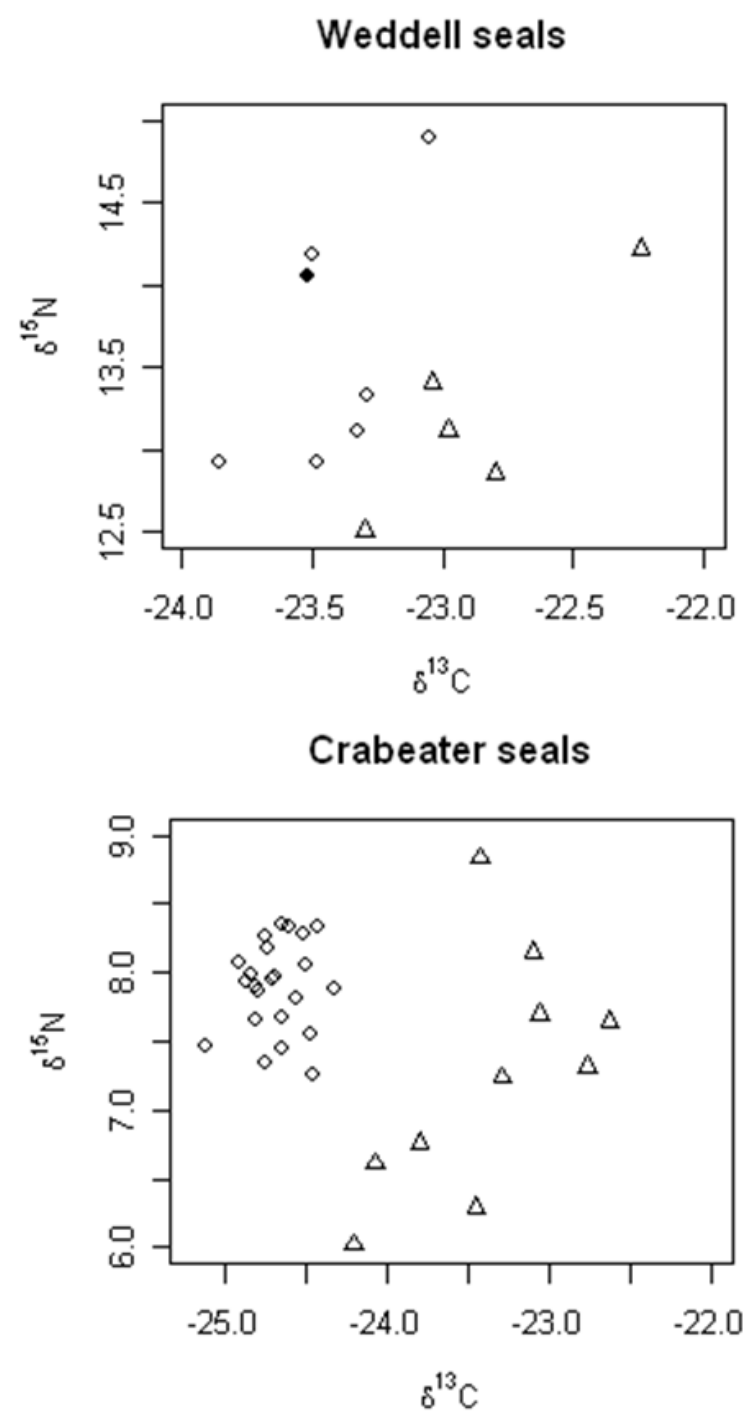

Ringed seals

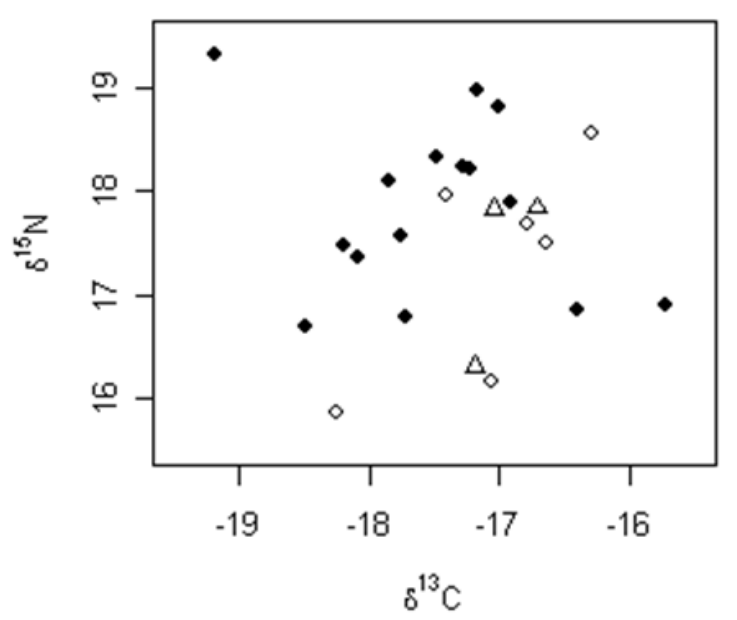


Fig. 4 Relations between $\mathrm{Hg}$ concentrations (in $\mu \mathrm{g} / \mathrm{g} \mathrm{dw}$ ) and $\delta^{15} \mathrm{~N}$ values (in \%o) (A), $\mathrm{Hg}$ concentrations and $\delta^{13} \mathrm{C}$ values (in \%o) (B), and $\delta^{15} \mathrm{~N}$ and $\delta^{13} \mathrm{C}$ values (C) in fur of the seven phocid species, with means \pm Standard Errors. The three geographical regions are shown by circles, solid thin for Denmark, dashed for Greenland and solid thick for Antarctica. Note that the $\mathrm{Hg}$ concentrations are plotted on a logarithmic scale
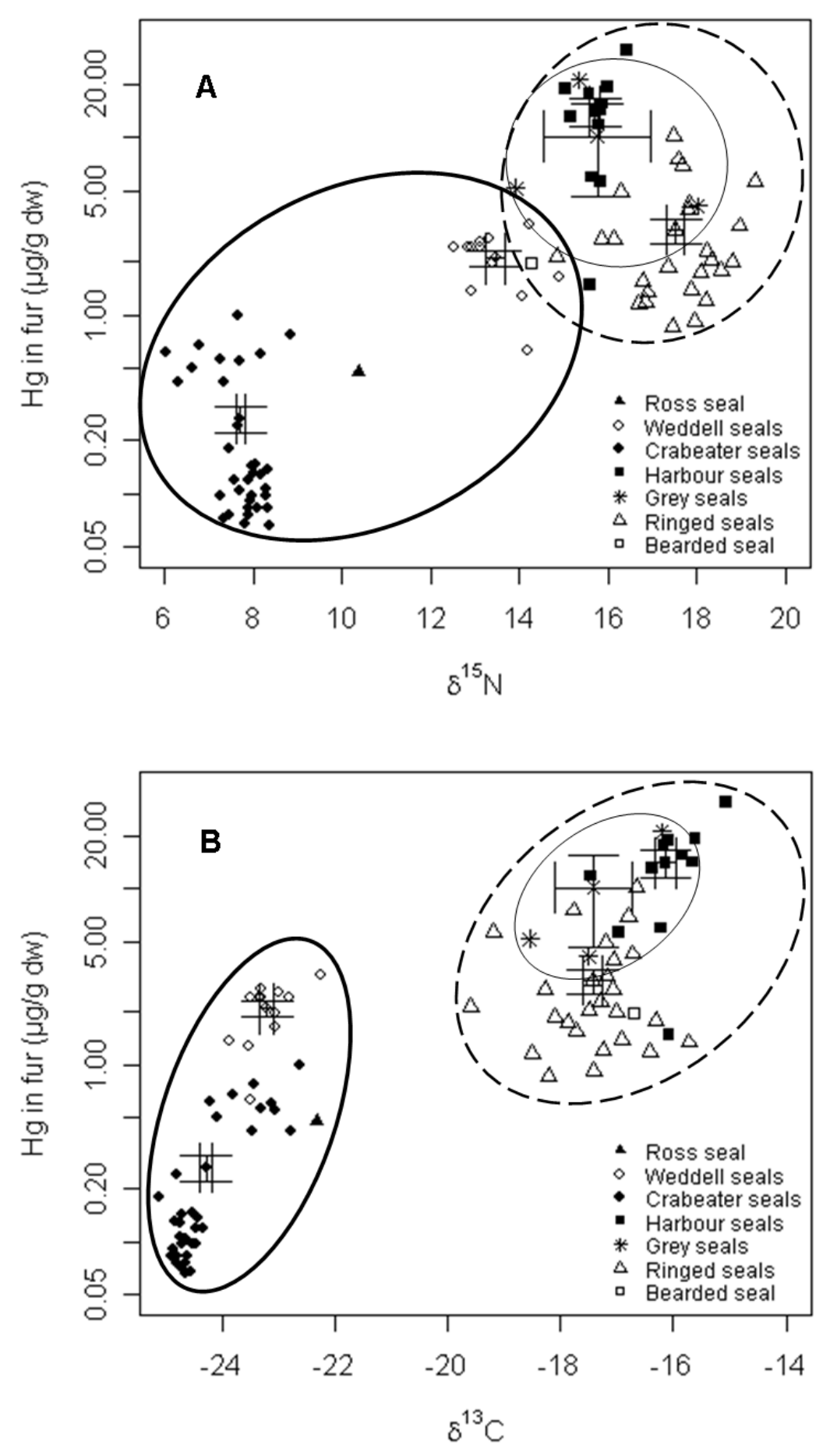


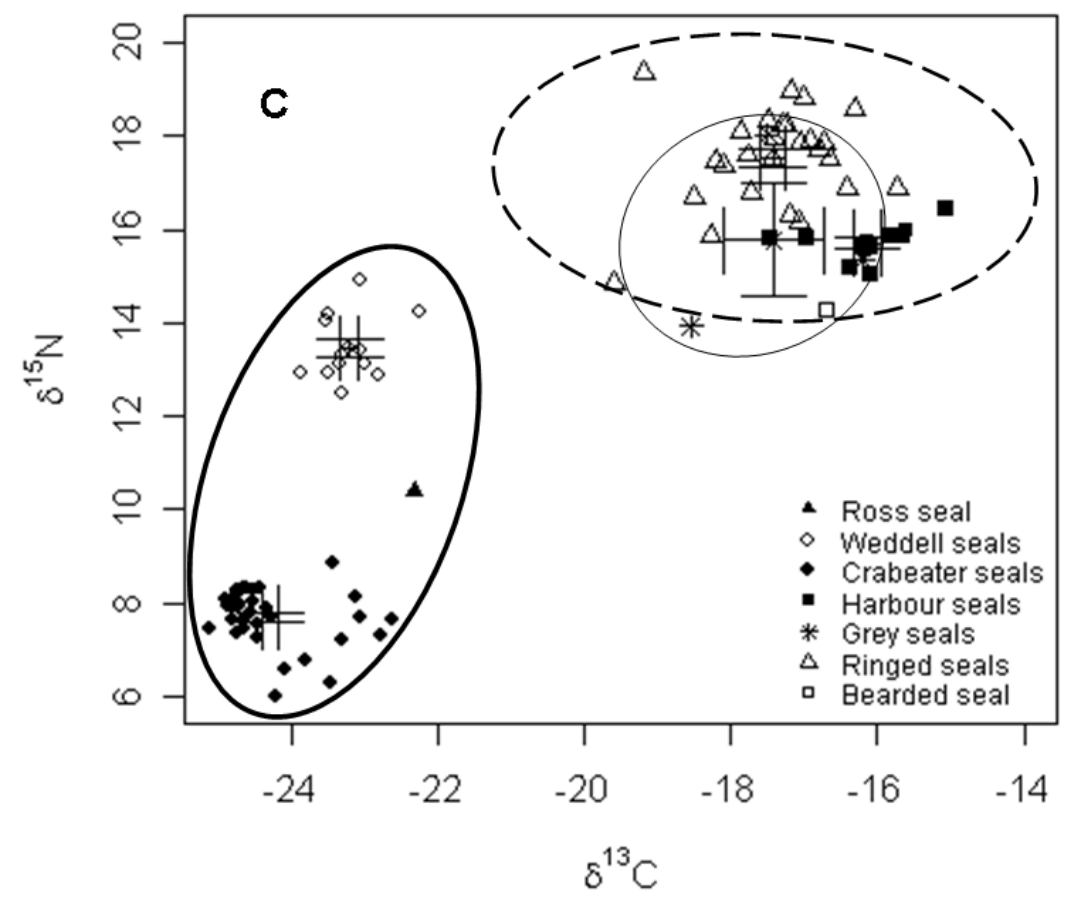


Table 1 Geographical areas and seal species with number of individuals $n$ in parentheses, age classes $(\mathrm{ND}=$ Not Determinate $)$ and genders of the individuals $(\mathrm{M}=$ Male, $\mathrm{F}=$ Female $)$

\begin{tabular}{|c|c|c|c|c|c|}
\hline Area $(n)$ & Species (n) & Yearling & Juvenile & Adult & ND \\
\hline & & $\mathrm{M} / \mathrm{F}$ & $\mathrm{M} / \mathrm{F}$ & $\mathrm{M} / \mathrm{F}$ & $\mathrm{M} / \mathrm{F}$ \\
\hline \multirow[t]{3}{*}{ Antarctica (46) } & Ross seal (1) & - & - & - & $1 / 0$ \\
\hline & Weddell seal (12) & $1 N D$ & $5 / 1$ & $4 / 1$ & - \\
\hline & Crabeater seal (33) & - & $11 / 10$ (2ND) & $4 / 6$ & - \\
\hline \multirow[t]{2}{*}{ Denmark (6) } & Harbour seal (3) & $1 / 0$ & $2 / 0$ & - & - \\
\hline & Grey seal (3) & - & $0 / 2$ & $1 / 0$ & - \\
\hline \multirow[t]{3}{*}{ Greenland (33) } & Harbour seal (8) & - & - & $5 / 2$ & $0 / 1$ \\
\hline & Ringed seal (24) & $9 / 6$ & $4 / 2$ & $1 / 2$ & - \\
\hline & Bearded seal (1) & - & - & $1 / 0$ & - \\
\hline All (85) & & $10 / 6$ (1ND) & $22 / 15$ (2ND) & $16 / 11$ & $1 / 1$ \\
\hline
\end{tabular}


Table 2 Mercury concentrations and stable isotopic ratios of nitrogen $\left(\delta^{15} \mathrm{~N}\right)$ and carbon $\left(\delta^{13} \mathrm{C}\right)$ (mean values \pm standard error SE and range) in fur samples of the various phocid species from the different geographical areas

\begin{tabular}{|c|c|c|c|c|c|c|c|}
\hline \multirow[t]{2}{*}{ Area } & \multirow[t]{2}{*}{ Species } & \multicolumn{2}{|c|}{$\mathrm{Hg}(\mu \mathrm{g} / \mathrm{g} \mathrm{dw})$} & \multicolumn{2}{|c|}{$\delta^{15} \mathrm{~N}(\% 0)$} & \multicolumn{2}{|c|}{$\delta^{13} \mathrm{C}(\%)$} \\
\hline & & Mean \pm SE & Range & Mean \pm SE & Range & Mean \pm SE & Range \\
\hline \multirow[t]{3}{*}{ Antarctica } & Ross seal & \multicolumn{2}{|c|}{0.48} & \multicolumn{2}{|c|}{10.38} & \multicolumn{2}{|c|}{-22.31} \\
\hline & Weddell seal & $2.09 \pm 0.21$ & $0.63-3.22$ & $13.46 \pm 0.21$ & $12.51-14.89$ & $-23.2 \pm 0.12$ & $-23.86-(-22.24)$ \\
\hline & Crabeater seal & $0.26 \pm 0.04$ & $0.07-0.99$ & $7.7 \pm 0.11$ & $6.02-8.84$ & $-24.28 \pm 0.12$ & $-25.11-(-22.63)$ \\
\hline \multirow[t]{2}{*}{ Denmark } & Harbour seal & $7.79 \pm 1.99$ & $5.63-11.77$ & $15.75 \pm 0.05$ & $15.65-15.82$ & $-16.87 \pm 0.36$ & $-17.46-(-16.21)$ \\
\hline & Grey seal & $10.11 \pm 5.47$ & $4.11-21.03$ & $15.76 \pm 1.20$ & $13.92-18.03$ & $-17.41 \pm 0.68$ & $-18.54-(-16.20)$ \\
\hline \multirow[t]{3}{*}{ Greenland } & Harbour seal & $16.27 \pm 2.86$ & $1.49-30.60$ & $15.69 \pm 0.16$ & $15.03-16.44$ & $-15.86 \pm 0.15$ & $-16.37-(-15.06)$ \\
\hline & Ringe & $3.06 \pm 0.49$ & $0.87-10.28$ & $17.64 \pm 0.18$ & $15.86-19.33$ & $-17.33 \pm 0.16$ & $-19.18-(-15.72)$ \\
\hline & Bearded seal & \multicolumn{2}{|c|}{1.97} & \multicolumn{2}{|c|}{14.26} & \multicolumn{2}{|c|}{-16.71} \\
\hline All & & $3.45 \pm 0.61$ & $0.07-30.60$ & $12.75 \pm 0.47$ & $6.02-19.33$ & $-20.76 \pm 0.39$ & $-25.11-(-15.06)$ \\
\hline
\end{tabular}

